\title{
SACRIFICIAL BODIES AND THE BODY OF THE TEXT IN ARISTOPHANES' LYSISTRATA
}

\author{
Judith Fletcher \\ 'Why is inert Matter female and the animating Nous male, please?' \\ 'Because earth is the Mother, because all beautiful things spring from her, \\ trees and flowers and creatures.' \\ A.S. Byatt Angels and Insects ${ }^{1}$
}

Byatt's characters, the Victorian gentlewoman who asks the question and the poet who answers, articulate an enduring notion of Western popular and intellectual culture. The association of women with matter and the body, men with form and the soul, is the legacy of ancient Greek thought which gendered the physical universe according to social convention: women were considered to be passive and therefore acted upon by the formative male principle. Examples of this bilateral symmetry include preformation theories of conception which suggest that a mother only provides the fetus with its raw material, while the father's seed organises that undeveloped material into its human form. ${ }^{2}$ This is a value-laden distinction, as we see from ancient philosophy which privileges the masculine soul over the feminine body and aligns men with the intellect but women with the baser corporeal passions. ${ }^{3}$ Literary representations reinforce this alignment: Euripides' Phaidra, whose attempts at rational control are undercut by her bodily desires, corroborates such a distinction; so do hysterical maidens like Io, stung by the exigencies of her body and put back in order by the organising force of Zeus (Aesch. Suppl. 575-9). Not surprisingly the mind/body duality informed gynaecological theory by which male doctors interpreted and 'cured' women's bodies. As Robert Con Davis puts it:

The figure of the gynecologist evokes and confirms cultural authority in the assumption of an immovable reference of underlying form (eidos)form that stands in relation to an amorphous female, suggesting the male as a stylus writing on the soft, feminine slate of the woman's body. ${ }^{4}$

The concept of man as the formative principle, woman as material, naturally informs ancient poetics, as the previous quote suggests. The creation of literature, a predominantly male activity, is by analogy a process of arranging inchoate matter into its textual form. The female Muses provide the material, but it is the role of the poet to shape that material into text. This gendered symmetry is ubiquitous in all aspects of ancient thought: a rational person's soul controls his body; men dominate women; doctors use reason to cure and control women's bodies; sperm shapes formless feminine stuff into humanity; poets write texts. 
Of course such a tidily balanced set of ideas can easily collapse, as it so often does in the mythopoetic imagination of the Greeks. In this paper I examine how Aristophanes' Lysistrata temporarily disturbs and then restores the established symmetry between body and female, form and male. That is to say, the women's appropriation of political and economic power in the play signifies a disruption of the conventional categorisation of body and form. When we consider the Lysistrata in terms of its deep structural alignments it is obvious that the women become associated with the formative principle, while the men are, until the end of the sex strike, determined in relation to their bodies. This may sound overly abstract and theoretical, but an awareness of this fundamental set of oppositions helps us to appreciate a system of metaphors sustained throughout the comedy. I am particularly interested in the formative nature of the women's oath in the prologue - the oath to give up sex until the men give up warwhich surprisingly has been given short shrift by critics and commentators. The unique transformative properties of the oath are suggested by the semantic range of the term horkos which covers both the spoken part of the oath and the sacrificial victim itself: language and the body somehow become one and the same in this word; or perhaps it might be more accurate to say that language inscribes the body and gives it meaning. My analysis will explore how the dynamic force of women's language, the oath, helps to shape and define the material world of the drama; for language is the 'animating Nous', the formative principle of this, and indeed of all, drama. The language of the Lysistrata is especially concerned with the body, with defining it, limiting it, and making it function in a particular way. As such it exemplifies a principle of Lacanian psychoanalysis: that language brings the body into the symbolic order, that it divides the body into discrete areas (erogenous, for example) with specific meanings and even that language brings 'things' into existence. From this theoretical perspective language does more than simply refer to the material world, but is as Judith Butler suggests 'also the very condition under which materiality may be said to appear'. 5

The oath belongs to a special category of language: it is a speech act or performative utterance, and as we shall see, it is the patterning agent of the play. In other words the Greek wives 'do things with words', to borrow J.L. Austin's famous title, and in essence their oath gives the drama its direction and form. ${ }^{6}$ As a force which combines both language and social practice, a speech act affects human action in the material world. Conventional language, in this case the oath, manifests a particular state of affairs, in this case a commitment to chastity and ultimately the end of the war. For women to take control of language, to 'do things with words', is a radical inversion: Lysistrata complains to the Proboulos that when she asked her husband what words were inscribed on the peace treaty, her husband told her to be silent. Men do things with words, they issue edicts and decrees, declare war or peace; women are to keep quiet (507-21). But the acquisition of performative discourse enables the wives to dissociate themselves from materiality and to specify the limits of their own and 


\section{JUDITH FLETCHER}

their husband's bodies. This is a difficult and only temporary dissociation, for the women are women after all, but they are under the leadership of the remarkable Lysistrata, a grand impresario who in effect takes over the role of author of this play. ${ }^{7}$ In view of Lysistrata's rhetorical powers, it is significant that there is no outlet for the poet's voice in the drama, no formal parabasis for the Aristophanic ego; instead the illusion is that Lysistrata controls the text. ${ }^{8}$ The oath then functions as a kind of script authored by Lysistrata and dictated to and enacted by her troupe of women. As a speech act the oath is by definition a performative force which helps to shape not only the social world, but also the physical world: the women's bodies become chaste, the men's bodies are sexually aroused. The husbands find that they must submit to the dictates of their bodies, while the wives shape the body of the text, the play.

This analysis of the play-reading it as a consequence of a speech act-invests the women's oath with more significance and power than it has usually been accorded. Matthew Dillon, for instance, suggests that this oath 'seems to be played as an end in itself, without serious consequences'. ${ }^{9}$ Certainly the scene goes for laughs, with a witty expropriation of Aeschylus' Septem (4245 ), and a ridiculous set of formal conditions ${ }^{10}$-and as Dillon points out the oath is not mentioned again until the Myrrhine and Kinesias episode. It would not be unlike Aristophanes, who is often more concerned with immediate humour than a cohesive plot, to simply introduce the oath as an episodic gag. But the Lysistrata is a well structured play, more cohesive than much of Old Comedy, with a fairly logical sequence of events. ${ }^{11}$ Its thematic and structural coherence suggests that this long, detailed oath-taking scene is more than a comic embellishment with little relevance to the rest of the play. Instead I argue that the oath taking scene signifies the conceptual realignment of body and form by distorting normative correlations between gender and sacrifice, and that this confusion of categories is a necessary prelude to the correction of tensions within the polis.

The women's oath is preceded by a sacrifice, which of course is another means of ordering the material universe, and the motif of sacrifice runs throughout the play linking the oath with the ensuing complications and their resolutions. The sacrificial motif offers a succinct commentary on the meaning and action of the comedy not only because an oath sacrifice illustrates so clearly how language can inscribe the body (the curse of the sacrifice makes the sacrificial body homologous to the body of the perjurer) but also because sacrificial practices and vocabulary become curiously warped in the Lysistrata. This is a play about the disruption of ritual, a disruption which signifies how deeply war has devastated the life and land of Greece. Yet a cessation of normal ritual behaviour is also a component of restoration and renewal, and thus the motif of the perverted sacrifice in this drama serves as a prelude to the recovery of peace and order. ${ }^{12} \mathrm{~A}$ subtext of transgressive sacrifice parallels the installation of gynaecocracy on the Acropolis, while the restoration of traditional gender roles at the end of the play corresponds to an implicit restoration of sacrificial practices. 
Helene Foley points out that this gynaecocracy is predicated on women's traditional religious roles, many of which would have been enacted on the Acropolis. Nicole Loraux imagines that the wives' oath makes them into virgins again, 'less a physical state than a social status', who serve time on the Acropolis as arrhephoroi (hence the weaving motif throughout the play). ${ }^{13}$ The older women gain control of the Propylaia on the pretext of offering sacrifice; they cite their own participation in various cults throughout their lives as evidence of their contributions to the state; and at least three of the women bear names of prominent contemporary religious officials. ${ }^{14}$ Lysistrata is probably a fictionalised version of Lysimache, priestess of Athena Polias, who of course would have presided over rituals including sacrifice on the Acropolis. Finally the oath itself seems to be an allusion to the oath of chastity that the Gerarai swear at the Anthesteria. ${ }^{15}$ In short, the Lysistrata is loaded with references to the cultic functions which provided Greek women with an opportunity to participate in the public sphere normally reserved for men. Lysistrata's short lived coup d'état is actually an extension of women's cultic roles, and since the men of Greece have abrogated their political authority by wasting public resources it is appropriate that women use their religious authority to enter the public sphere and put it back in order. Their efforts require a temporary gender inversion: women in armour, a magistrate in drag, husbands like Kinesias trapped in a household of neglected children. ${ }^{16}$ The skewed sacrificial code contributes to this gender inversion so typical of periods of renewal and frequently given cultic expression.

As I shall demonstrate, the act of sacrifice is traditionally encoded as a masculine activity, while the female body is aligned with sacrificial offerings: another manifestation of the gendered dichotomy of form and matter. The temporary breakdown of the associations between body and form/female and male is sustained by a distortion of a normative correlation between female body and sacrificial victim. Although the sacrificial motif runs throughout the play, three scenes in particular refer to the same elements of sacrifice: the assembly of wives at the beginning of the play, the oath taking ceremony, and the Reconciliation scene. It will become obvious that the oath-taking ceremony problematises the conventions of sacrifice in a way that corroborates the wives' expropriation of language and sexuality; oath and sacrifice become different manifestations of the same formative principle.

The sacrifice/horkos is the embodiment or incarnation of the oath/horkos: words made concrete. The language of the oath and curse overwrite the sacrificial body and thus bring it into the symbolic order. Burkert reminds us that:

In the language of the oath, the object of aggression that is to be 'struck' and 'cut' becomes virtually identical with the covenant itself. ${ }^{17}$

Heinrich von Staden explores the connection between body and word by elaborating on the possible etymological association of the terms horkos and herkos 


\section{JUDITH FLETCHER}

or 'boundary'. The oath-sacrifice creates new boundaries by violating what von Staden describes as the 'skin fence' of the victim's body, while

[i]n swearing an oath, one creates boundaries; one fences in oneself and those rendered complicitous by the oath; one binds through the efficacy of the oath's word magic. ${ }^{18}$

Sacrificial cutting helps to concretise the new boundaries established by the oath, and, as existing oath formulae suggest, sacrifice was a common feature of oath-taking ceremonies. There are several oath ceremonies staged in Attic drama, ${ }^{19}$ but of all the oaths performed on stage, only the Lysistrata features a sacrifice. Aristophanes often uses sacrifice to mark the implementation of the 'Great Idea', and such is his purpose here. ${ }^{20}$ Perhaps because blood sacrifice is too messy to perform on stage Aristophanic characters will offer libations, or their attempts at blood sacrifice will be thwarted or interrupted in some way. The Lysistrata combines these approaches by having the women substitute a vessel of wine for the victim.

The nature of the women's sacrifice requires further investigation, but for now I simply draw attention to the aspect of substitution in sacrifice. Like any ritual, sacrifice is a richly symbolic act. It signifies a system of beliefs, a perceived relationship with divinity, a means of perpetuating life and fertility. The multiple interpretations of this ritual attest to its dense complex of meanings. Angelo Brelich describes animal sacrifice as a 'symbol' of human sacrifice. As we know, several myths feature human victims replaced by animal victims; mythic representations of human sacrifice are parallelled by cultic enactments of animal sacrifice. Burkert suggests that animal sacrifice is symbolic reparation for the guilt incurred through hunting. ${ }^{21}$ Myths such as the substitution of a deer for Iphigenia suggest that for the Greeks animals substituted for human sacrifice as a means of deflecting the interest of a god away from mortal victims. ${ }^{22}$ Thus when Lysistrata offers a stamnion of wine in place of a boar at the oath ceremony, she is actually exploiting the semiotic plenitude of sacrifice in which one object 'stands in' for another. As we shall see, the ability to make one object substitute for another, a jug of wine as a boar or a woman as a sacrificial beast, is paradigmatic for the process of creating theatre in which people and objects represent something else. ${ }^{23}$

\section{Sacrifice and Gender}

Any literary or artistic allusion to human sacrifice emphasises how aberrant such a practice would be. Although Greek myth features young women and occasionally young men offered in sacrifice, there is scant evidence to suggest that such a practice ever existed in ancient Greece, as Dennis Hughes contends. ${ }^{24}$ What is important for my discussion is the high incidence of female victims in 


\section{SACRIFICIAL BODIES IN ARISTOPHANES' LYSISTRATA}

these narratives; conceptually women are somehow more easily associated with animal victims. Human victims such as Iphigenia substitute for animal sacrifice perhaps because the reproductive functions of a woman's body help to align her with animals. As Aristotle says, at puberty the blood of a woman flows 'like that of an animal that has just been stabbed'. Helen King discerns an analogy between menstrual blood and sacrifical blood in the myth of Pandora: the first woman appears in the world as a direct result of the first sacrifice. ${ }^{25}$ Thus in Acharnians (740-815) the Megarian attempts to sell his daughters as pigs intended for sacrifice to Aphrodite. The joke derives from the word for pig,

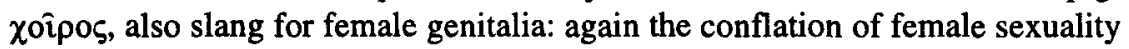
with the idea of sacrificial victim seems to be informed by women's alignment with materiality.

The logical extension of all this is that women cannot perform blood sacrifice themselves, or that if they do something is seriously amiss. The act of sacrifice is a way of imposing meaning and order on the body and material world, a 'masculine' activity. As Burkert explains, sacrifice, an act of ritualised killing, is sexualised: weapons take on a phallic association and of course the victim is conceived as feminine. ${ }^{26}$ This seems to be a universal principle. In her crosscultural survey Nancy Jay hypothesises that patrilineal societies bar women from blood sacrifice because they bear children:

Some of the most prominent... [features of ritual sacrifice] are gender related, such as the opposition between sacrificial purity and the pollution of childbirth, and a rule that only males may perform sacrificial ritual. In the polarity between blood sacrifice and childbirth, killing receives a positive value and giving birth a negative value. ${ }^{27}$

Sacrifice becomes a means of incorporating a young male into the social structure, and thus ritual killing replaces parturition as the means of continuing life. Burkert remarks on this gendered opposition in his discussion of Arkadian festivals which excluded women from certain sacrifices, but allowed them to enact the role of nurses to the new-born Zeus. Even the maenadic sparagmos, sometimes referred to as a sacrifice, illustrates the impropriety of female blood sacrifice, for the activity of the maenads is in fact the complete inversion of sacrifice: the animals are wild not tame, hunted rather than ritually selected, eaten raw rather than cooked. ${ }^{28}$ Women do not seem to be able to perform sacrifice correctly; their attempts, as registered by myth, are dangerous and perverse.

Marcel Detienne concludes from myths of murderous wives that women were restricted from performing blood sacrifice except in limited situations because of a latent fear that they could kill their husbands with their sacrificial implements. According to Detienne blood sacrifice is exclusively a masculine activity at all levels. Robin Osborne has challenged this rather categorical view of gender roles in sacrifice by arguing that it bars women from all aspects of sacrifice, which of course is not the case; ${ }^{29}$ but more germane to my discussion is wom- 


\section{JUDITH FLETCHER}

en's exclusion from shedding the blood of other living creatures. To this end King responds:

...their exclusion from this act [ritual killing], within the context of their general inclusion in sacrifice, forms part of a wider system of classification of male and female, in which women do not perform culturally significant acts which involve shedding the blood of others (war, sacrifice, butchery). ${ }^{30}$

King's observations help to illuminate the Lysistrata's organisational principle, and of course the blurring of categories based on that principle, which sustain the meaning of the play. The women declare a war of sorts in their peace efforts, and they offer a libation, a sacrifice which corresponds to the spondai of a peace treaty, but one which is treated as a blood sacrifice. War, sacrifice and butchery, 'culturally significant acts which involve shedding the blood of others' are now dangerously close to becoming the activities of women.

\section{The Assembly of Women}

With all these considerations in mind let us turn to the events of the play, which begins as Lysistrata marshals her troops. Women's overdetermination in relation to the body is well established in this scene which introduces the sacrificial motif, and makes a few suggestive allusions to the similarities between woman and victim. Actual sacrifices involved selecting the animal, immolating and burning the selection and distributing the meat among the polis. ${ }^{31}$ The early part of the prologue invites us to keep the ritual of sacrifice in mind and if we respond to this invitation we discern an interesting pattern.

When the Spartan Lampito arrives, Lysistrata and Kalonike admire her splendid physique, apparently prodding and fondling her as they do so. Lysistrata greets Lampito:

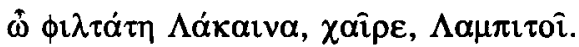

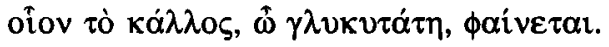

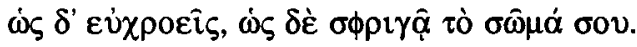

Dearest Spartan girlfriend, welcome Lampito.

How radiant you are, darling!

What a good colour and firm body.

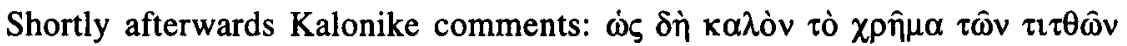

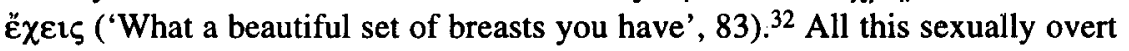
admiration would seem like nothing more than a lewd grab for laughs, remind- 
ing us as Lauren Taaffe suggests that these 'women' are really men in drag, but then Lampito makes a rather strange objection: that she is being felt up $\underset{\alpha}{\tau} \pi \varepsilon \rho$ iapeiov ('like I'm a sacrifical victim', 84). The scholiast explains that 'those who are about to make a sacrifice touch the victims to see if they are sleek'. The scene thus parallels the preparatory stage of the sacrifice in which the most attractive unblemished victim is admired and then selected. ${ }^{33}$ As we shall see, a similar contact is required when the women take their oath.

The sacrificial motif occurs again when Lysistrata asks her panhellenic assembly if they want to help her end the war. Myrrhine responds that she would

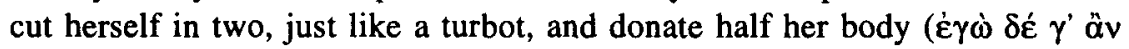

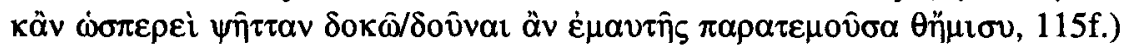
if it would help the cause. A turbot is not exactly the kind of animal one might think of as a sacrificial offering, but indeed certain kinds of fish and even eels were offered by the Greeks as oblations. ${ }^{34}$ That Myrrhine would volunteer to cut herself recalls the sacrificial act and the important activity of dividing the sacrificial spoils among the community for consumption. ${ }^{35}$ It is also interest-

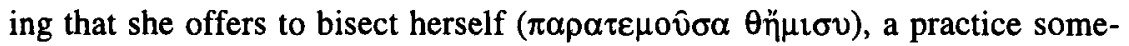
times associated with oath rituals, although not all such sacrifices were necessarily consumed.$^{36}$ Myrrhine's offer combines with Lampito's sacrificial allusion to emphasise the association of women's bodies, especially the sexual parts of their anatomy, with the bodies of sacrifices and to foreshadow some of the activities of the oath sacrifice.

\section{The Women's Oath and Sacrifice}

The assembly scene plays with the correlation between woman and sacrificial offering, an unwholesome idea in itself, but the scene presents the even more uncomfortable suggestion that the women who inspect and touch Lampito, the victim as it were, are prepared to assume an active role in their sacrifice. The oath-taking sacrifice refers to this preceding scene, but now highlights women's function as sacrificers. Such a serious conspiratorial oath requires a ceremony; Lysistrata makes preparations to sacrifice a sheep, but there is controversy about the suitablity of the proposed victim. Kalonike's objection that a blood sacrifice in a shield is inappropriate reminds us of the transgressive nature of women's blood sacrifice, for although these women do not actually kill a real animal, they will use language to suggest that they do. Detienne's suggestion that sacrificing women provoke latent anxieties about husband-murdering women resonates with the motif of the murderous Lemnian wives which underscores this scene. ${ }^{37}$ Detienne also relates women's exclusion from blood sacrifice to their exclusion from political life:

As a general rule, by virtue of the homology between political power and sacrificial practice, the place reserved for women perfectly corre- 


\section{JUDITH FLETCHER}

sponds to the one they occupy—or rather, do not occupy—in the space of the city. Just as women are without the political rights reserved for male citizens, they are kept apart from the altars, meat, and blood..$^{38}$

That women would take over the role of sacrificers parallels their occupation of the Athenian citadel and expropriation of political power. Yet despite the initial possiblity that the women will really perform a blood sacrifice, everyone agrees that a jar of Thasian wine would be most appropriate. ${ }^{39}$ The sacrifice thus recalls the ritual libation of a peace treaty, yet the jar of wine is referred to throughout as if it were a living victim, the sacrificial preliminary to war. So the image of a blood sacrifice is not put to rest: Lysistrata refers to the jug as the sphagia (206) and the 'boar' (202) and says that she will 'slaughter' it

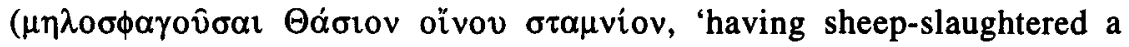
Thasian jar of wine', 196). Wine is a frequent complement to animal sacrifice and by itself may function as a replacement for a living victim, so the pretence here is natural and obvious. ${ }^{40}$ The sacrifice simultaneously exploits the stereotype of bibulous women and wine's similarity to blood; but it is also significant that by using the terms of blood sacrifice the women use language to create reality: they call the wine jug a boar and in a sense it becomes one. By acting as if they are indeed performing a blood sacrifice Lysistrata's troupe of women stage a disturbing scenario. If we bear in mind the behaviour of the women and their allusions to sacrifice in the Assembly scene, we see that the oath-taking scene distorts the sacrificial code in such a way that it disturbs normative gendered roles.

The selection of the victim requires approval of its physical properties. When the stamnion arrives Lampito voices her enthusiatic admiration: $\phi \varepsilon \hat{v} \delta \hat{\alpha}$, $\tau$ òv

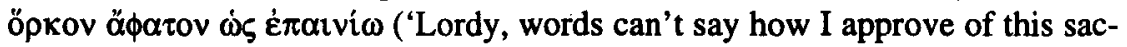
rifice', 198: note that here tòv öpkov means 'sacrifice'). Myrrhine and Kalonike express the same kind of admiration (phrased in qualitative adverbs and adjectives) that they did for Lampito who complained of being treated like a victim:

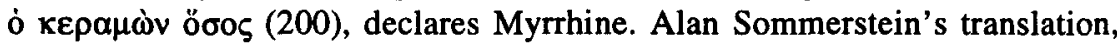
'what enormous hardware', charges her comment with a similar sexual veneration devoted to Lampito's breasts and buttocks. When the victim is

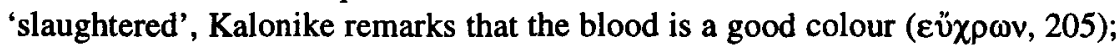
just as earlier Lysistrata had remarked on the good colour of Lampito: $\omega \varsigma \delta^{\prime} \varepsilon v-$ 'xpozị.

It was obvious that the Athenian women were touching Lampito; likewise the women, including Lampito now, crowd around the stamnion of wine eager to touch it as if it were a blood sacrifice. Indeed Lysistrata instructs them to

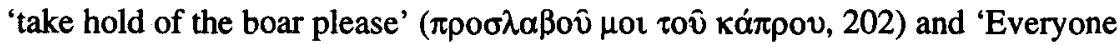
take hold of the cup' ( $\lambda \dot{\alpha} \zeta v \sigma \theta \varepsilon \pi \hat{\alpha} \sigma \alpha \imath \tau \hat{\zeta} \varsigma$ кú $\left.\lambda_{1} \kappa \rho \varsigma, 209\right)$. As we noted when Lampito complained about being fondled, ritual touching of the victim was part of an oath sacrifice. In oath sacrifices, however, physical contact had an ancillary purpose: it helped to identify the oath taker with the victim, and to transfer 
the curse (embodied by the victim) to the perjurer.$^{41}$ If the women had observed protocol in their oath this act of sympathetic magic would have enhanced their association with oblations: what happens to the victim during the oath ceremony will fall on the head of the perjurer. But again this particular horkos has some unusual aspects: rather than calling a curse upon themselves, the women wish that the wine turn to water if the oath is broken and that they will drink wine if the oath is kept. The women's dissociation from the sacrificial body is so complete that they depart from the conventional identification with victim. ${ }^{42}$

It was customary to pour peace and oath libations on to the ground, but the pretence of blood sacrifice is maintained in this ceremony which conflates symposiastic conventions of drawing lots with the practice of dividing the sacrificial meat among men. The women eagerly manoeuvre into position for their share

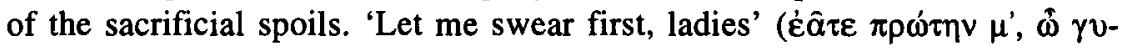

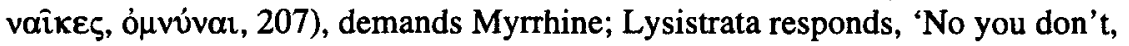

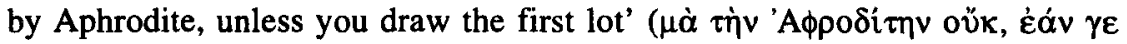
$\mu \grave{\eta} \lambda \dot{\alpha} \chi n s, 208)$. This apportioning of the 'victim' alludes to the important aspect of distributing the sacrifice and thus corresponds to Myrrhine's offer of her own body earlier. But according to Eustathius (5.24.10), oath-takers did not partake of the sacrificial spoils because the victim represented the embodiment of the curse. ${ }^{43}$ That the women actually consider consuming their sacrificial wine represents another perversion of traditional ritual practice.

Although the oath-taking ceremony only features a simulated blood sacrifice, the women's active hieratic roles distort the sacrificial code in several ways. The oath with all its transgressive aspects reinforces the women's new position of dominance, and underscores the force and significance of their oath of chastity. According to Jay, sacrifice by men complements or even replaces the female role of parturition. By taking on the role of sacrificers and by creating the illusion, humorous as it may be, that they are killing a beast, a boar, the Greek wives have withdrawn from their function as childbearers. When the Proboulos complains that women have no part in the war, Lysistrata responds that indeed we do 'by bearing sons and sending them out as hoplites' (589f.). The chorus women also claim: 'I have a share in the common wealth; for I contribute men' (651). Women took over the role of sacrificers in their oath-taking essentially because their childbearing capacity, the binary opposite of sacrifice, is wasted and abused. As they simulate a blood sacrifice, a masculine activity, the women vow to abstain from sex, the necessary prerequisite for child-bearing.

\section{The Body of the Text}

As the younger wives complete their oath and sacrifice, the older women who have been conducting their own version of a sacrifice on the Acropolis let out the ololuge (240), the ritual shout that women make after a traditional blood sacrifice. The offstage cry serves to connect the sacrifices of both groups 


\section{JUDITH FLETCHER}

of women, and to universalise the new active role of women as sacrificers. The spectators must now imagine that the skene no longer represents the women's homes but the Propylaia: a type of scenic transformation not unknown to Attic drama. The shift helps to conflate the domestic and political spheres in this play about transformations. Essentially the horkos has manifested this transformation by giving the women political power; their commitment to chastity enables them, as we shall see in the Myrrhine and Kinesias episode, to dictate public policy. Having sworn their oath the troupe disbands, although some of the women remain on the Acropolis. The covenant is not explicitly mentioned again for several hundred lines, nor does it entirely prevent the women on the Acropolis from trying to sneak off to their husbands. Nevertheless the oath has performed an important programmatic function. It set women in the role of sacrificers, and thus aligned them with the formative principle; it gave women power over a social situation, and control over the material world, their own bodies; and finally it allows women to use language to create reality, for the oath is a kind of prescriptive text which functions on a deep symbolic level throughout the remainder of the play. The women swore never to let a man

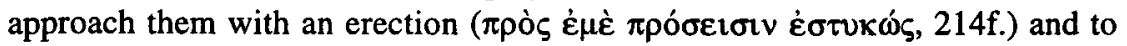

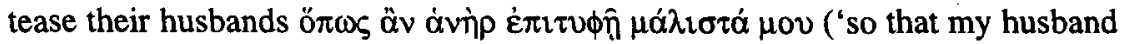
will burn for me', 221f.). The old men and women of the chorus provide a symbolic enactment of these words: the men approach carrying $\chi \lambda \omega \rho \hat{\alpha} \varsigma \ldots . . \dot{\varepsilon} \lambda \dot{\alpha} \alpha \zeta$ ('fresh olive trunks', 255), phallic symbols which they intend to set on fire (267f.) or bash against the locked doors of the Propylaia. But the women are able to ward off the men, and the parodos thus replicates the conditions of the oath. To pick up an image which I used earlier, the play becomes the body of the text which is guided and shaped by the authorial control of Lysistrata and the performative force of the women's oath.

The old women enter with water, the old men with what they describe as Lemnian fire (Lys. 299). Martin and Bowie read this as a reference to the myth of the Lemnian women and the associated rite of the purophoros; Faraone imagines the performance of the parodos as a visual allusion to iconographic traditions in which suppliant women at an altar are threatened with fire. ${ }^{44}$ On a broader level the action of the barring of the Propylaia signifies the women's new chastity: the Acropolis itself takes on the properties of a woman's body. The sanctity of the Acropolis has often been linked to the virginity of Athena; the impenetrability of the virgin symbolises the security of the citadel. Sealing their bodies is paradigmatic for sealing the Acropolis; hence the women's barricade seems to derive from the oath as well. ${ }^{45}$ In fact this parodos is a nexus of mutually enhancing significations to which I add the following observations. If we consider the agon between the men and women in terms of the sacrificial motif which I have identified, then we are struck by the men's desire to incinerate the women with fire (268-70, 322-24 and 340) and the women's fear of this event (373). Most blood sacrifices involved burning the victim, and so the firebearing old men are yet another manifestation of the male-as-sacrificer equation. 
That their fire is put out by the old women enhances the transgressive quality of this play; for the prologue established that women had taken over the role of sacrificers. It is appropriate, then, that the women of the Chorus divest the gerontes of their control of fire hence preventing them from burning the women like sacrificial beasts.

The first episode, featuring the agon between Lysistrata and the Proboulos, the embodiment of civic authority, not only demonstrates how successfully the women have gained control of Athenian political and financial affairs, but also implies that they can turn men into oblations as well. The rhetorical and physical contest culminates in Lysistrata dressing the Proboulos as a woman, and then as a dead woman; once again she takes on an authorial role by compelling her victim to be something other than he and we thought he was: just as she could transform the stamnion of wine into a sacrificial boar she now turns the Proboulos into a woman. By decking him out with a few ornaments, a veil and wreath, the women essentially transform the man into a sacrificial offering which is adorned only to be led away to the slaughter. The scene simultaneously alludes to the transformative potential of the theatre, in which objects and people may be metamorphosed, and the conceptual mutability of a sacrifice in which animals, objects and human beings can be interchanged.

But in the next episode things start to unravel. Abstinence is not a natural condition for women, according to Greek thought. One by one the women try to sneak away from the Acropolis, as their bodies' desires betray their oaths. The third defector pretends to be pregnant by tying the sacred helmet under her dress (743). It is as if the script created by Lysistrata has been forgotten, and the women will capitulate to a kind of theatrical anarchy, ignoring the direction of their playwright, Lysistrata, and creating a new play within a play, for which they themselves will assign meanings to objects. Such anarchy would result in the women losing control not only of themselves but their husbands, the state and the material universe. Simulated birth threatens the gains achieved through simulated sacrifice, yet it is performative language again which affirms the women's commitment. Lysistrata produces a new script, the oracle of Zeus, the god of oaths whom the women invoked in their oath. Language thus defines and limits the body once more, and without hesitation the women take control of their physical urges. Like the oath, the oracle affects (rather than describes) a situation; in fact the situation achieved is identical in both cases, sexual abstinence. ${ }^{46}$ The two speech acts share another commonality: both are religious in nature, which makes them particularly authoritative. The women swore by Zeus to remain celibate, and he reminds them of this obligation through the oracle.

It is Lysistrata who mediates these communications with the divine, an activity which enhances her authorial status in the play; and she assumes full authorial control in the Myrrhine and Kinesias episode where she gives what seem to be stage directions to Myrrhine. Here we see the words of the oath creating action and reality, giving form to matter, dictating the conditions of men's bodies. Myrrhine practises all the allurements specified in the oath: the wives 


\section{JUDITH FLETCHER}

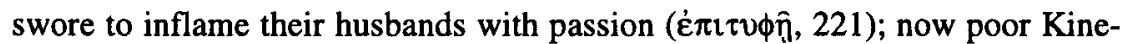
sias is grilled (ó $\pi \tau \hat{\alpha} v, 839$ ) and roasted just like a sacrifical victim ${ }^{47}$-the inversion of gendered roles in sacrifice is thus complete. It is interesting that Myrrhine actually uses a man's oath when she swears by Apollo (917), a subtle reminder of this reversal. The oath of chastity is mentioned several times: by Lysistrata in her instructions to Myrrhine (841), and twice by Myrrhine herself as she teases her tormented husband. And the oath does its work, for the frustrated Kinesias realises that his only chance of sexual gratification is to argue for Peace before the Council - precisely what his wife told him to do.

\section{Reconciliation}

In the oath ceremony the audience imagined Lysistrata turning a jug of wine into a sacrificial boar through the power of language. In the Reconciliation scene she performs another transformative act by presenting a naked woman and making her represent Greece. David Konstan observes that since women from all over Greece organised themselves into a coherent body for the sex strike, the image of the female body as a representation of Greek unity is very apropos. ${ }^{48}$ Certainly the homology between a woman's body and 'Mother Earth' is at play here, a reminder of woman's materiality, but this silent and objectified woman is specifically named 'Diallage', the embodiment of the pleasures of peace. Aristophanes uses the female body as an allegorical figure for certain abstract qualities in other plays, as if women's connection with materiality can be used to concretise those abstractions for the stage. ${ }^{49}$ Lysistrata performs this theatrical tour de force in order to restore the conceptual system which aligns women with the body and men with the formative principle. Certainly in this case the focus on the body of Diallage re-establishes women in the sphere of the material, while men's organisation of her body into discrete areas that they can occupy and regulate means that they are now restored to their controlling roles..$^{50}$

Lysistrata begins her task of reconciliation by reminding the Spartan and Athenian ambassadors that they shared sacrifices at the Panhellenic games (1129-31), which is indeed what they seem to be doing in this scene. The sacrificial subtext implicitly reinstates woman's body as an oblation; as though the two men go through the procedure of admiring and approving the victim and then distributing the spoils of sacrifice. The men admire the physique of Diallage, just as their wives admired Lampito, and then the wine jug, with a liberal sprinkling of qualitative adverbs. The Spartan ambassador declares that Dial-

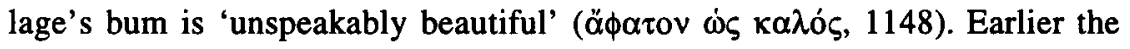
Spartan woman, Lampito, used a similar phrase to express her admiration of the

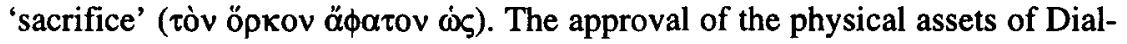
lage resembles that of the Greek women for Lampito and the Theban and Corinthian women, and then later for 'the enormous hardware' of the horkos. 'I've never seen a nobler woman!' declares the Spartan; 'and I've never seen a prettier 
crotch,' responds the Athenian. United by their admiration of Diallage, the ambassadors touch her (as the deictics suggest) and claim various portions of her anatomy, a reminder of the ritual touching of the victim (cf. Lampito and the wine jug). The Athenian ambassador, for example, suggests 'hmm...well then

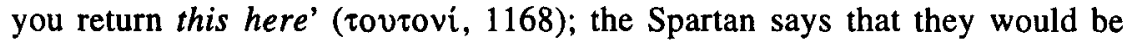

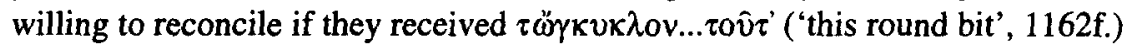
and quite naturally he touches Diallage's buttocks which correspond to 'Pylos, which we've wanted and fondled for a long time'.

Diallage functions as a text, or contract-matter organised by male language. This is an important moment in the re-establishment of male supremacy, for until now it has been women who have named objects and made them what they are: the stamnion of wine became a body through women's language; the helmet became an unborn child. If nothing else, this play reminds us that no object truly exists before the act of signification, if not in psychoanalytic sense of the material world, then at least in the world of ritual and theatre. Just as the wine sacrifice became the oath, the horkos or covenant among women, Diallage becomes the covenant among men. Men become sacrificers again, inscribing the female body with their words, making it mean something. Yet Lysistrata restrains the men from sexual fulfilment by ordering them to remain pure until they swear oaths with each other: 'and then each man will take his own wife and go home' (1185-87). Thus their peace oaths counteract the women's oath of chastity, for the consequence of these male-uttered oaths is sex, while the surrogate sacrifice is once again the female body. And as a reward for having honoured their covenant, the women will indeed drink wine at the ensuing festivities.

But what about Lysistrata herself? She mediated a quarrel between the women over who got to drink the wine first, just as she now mediates a quarrel between their husbands over the apportioning of their 'sacrificial victim', but in the exodos when husbands and wives unite she remains strangely unattached. Her identification with Lysimache, priestess of Athena Polias, is persuasive, but she is virtually an armed Athena figure who produces her shield for the oath ceremony and then prevents the theft of her helmet from the Acropolis. It is fitting then that she does not submit to any husband. For as Athena herself says in Eumenides (another drama set on the Athenian Acropolis), she takes the male part except in marriage (Eum. 737). For a brief moment she grants women power over language and sacrifice, she re-admits them into the matriarchal core of the city, but only as a means to an end. The wealth of the Acropolis, the fertility of woman and land have been wasted in an interminable and futile war, but once the war is over Athena can take the male part once again. ${ }^{51}$

Wilfrid Laurier University 


\title{
JUDITH FLETCHER
}

\author{
NOTES
}

1. A.S. Byatt, Angels and Insects (London 1986), 228.

2. The most famous of these is Apollo's argument that the mother only provides nourishment to the fetus at Aesch. Eum. 658-61. Daryl McGowan Tress, 'The Metaphysical Science of Aristotle's Generation of Animals and its Feminist Critics', in Julie K. Ward (ed.), Feminism and Ancient Philosophy (New York 1996), 31-50, at 37f., offers these lines as a 'stunning example' of the theory of preformationism or the idea that the father plants a homunculus in the mother's body. Medical writers did recognise women's contributions to the 'genetic' make-up of the fetus, and an ancient audience may have recognised Apollo's chicanery; but versions of Apollo's theory had been espoused by Anaxagoras and other physical philosophers. See G.E.R. Lloyd, Science, Folkore and Ideology: Studies in the Life Sciences in Ancient Greece (Cambridge 1983), 86-94.

3. Morag Buchan devotes a chapter to 'The Masculine Soul' (M. Buchan, Women in Plato's Political Theory [New York 1999], 10-52); Elizabeth Spelman surveys the influence of a gendered mind/body distinction in Plato and Aristotle on European thought until the present (E. Spelman, 'Woman as Body: Ancient and Contemporary Views', Feminist Studies 8.1 [1982], 109-31). Certainly Aristotle recognised women's material contribution to conception as being unique and necessary, but as Kathleen C. Cook, 'Sexual Inequality in Aristotle's Theories of Reproduction', in Ward (n.2 above), 51-67, at 54, points out, his own metaphysical theory evaluates the material as inferior.

4. R. Con Davis, 'Aristotle, Gynecology, and the Body Sick with Desire', in L.H. Lefkovitz (ed.), Textual Bodies (Albany NY 1997), 35-57, at 49. See also Page duBois, Sowing the Body: Psychoanalysis and Ancient Representations of Women (Chicago 1988), 154f., for a discussion of writing as a sexual metaphor for which a woman's body represents a text.

5. J. Butler, Bodies That Matter (New York 1993), 31; for an excellent discussion of the relationship between language and the body in Lacanian theory see B. Fink, The Lacanian Subject: Between Language and Jouissance (Princeton 1995).

6. The women's oath falls neatly into what Austin would call an 'explicit performative', both because of the oath formula and the 'accompaniments of the utterance', i.e. the sacrifice. More precisely, however, Austin, in his final lecture, categorises vows as 'commissives' whose effect is to 'commit a speaker to a certain course of action' (J.L. Austin, How to Do Things with Words [Oxford 1955], 76 and 157). For a discussion of drama itself as the pre-eminent form of a speech act see S. Petrey, Speech Acts and Literary Theory (New York 1990), 86-110.

7. The relationship between women and language in classical Greek drama is usually problematic. Laura McClure observes the subversive effects of women speaking outside the bounds of masculine control in Spoken Like a Woman: Speech and Gender in Athenian Drama (Princeton 1999). My reading of Lysistrata's rhetorical control differs from that of Lauren Taaffe, who attributes her assertive nature to the fact that the role would have been played by a male actor. Otherwise I am in agreement with her remarks regarding the metatheatric components of this play. See L.K. Taaffe, Aristophanes and Women (New York 1996), 60-65.

8. Lysistrata's agon with the Proboulos and her political advice (567-86) function as a parabasis-speech, although the agon between the semichoruses (in which the female chorus offer advice) contains parabatic elements. See J. Henderson, Aristophanes: Lysistrata (Oxford 1987), 149. I use his text throughout this article.

9. M. Dillon, 'By Gods, Tongues, and Dogs: The Use of Oaths in Aristophanic Comedy', $G \& R$ 42 (1995), 135-51, at 137; likewise Henderson ( $\mathrm{n} .8$ above, 90) describes the scene as 'entirely farcical'

10. Lysistrata is punctilious in her observation of protocol, and constructs an oath which covers the basic elements of the oath formula; for an outline of the components of the traditional oath see J. Plescia, The Oath and Perjury in Ancient Greece (Tallahassee 1970), 3.

11. On the structure of the Lysistrata see A.O. Hulton, 'The Women on the Acropolis: A Note on the Structure of the Lysistrata', G\&R 19 (1972), 32-36; J. Vaio, 'The Manipulation of Theme and Action in Aristophanes' Lysistrata', GRBS 14 (1973), 369-80. Although there are apparent incongruities in how the women swear to go home and tantalise their husbands, yet remain on the Acropolis, Vaio has successfully demonstrated that the play collapses the distinction between oikos and polis, so that the Acropolis in fact functions as an Athenian household once the women gain control. 


\section{SACRIFICIAL BODIES IN ARISTOPHANES' LYSISTRATA}

12. The motif of the interrupted ritual and transgressive sacrifice is enhanced by a series of allusions to the myth of the Lemnian women and the associated ritual of the purophoros which is preceded by a nine day period of fireless sacrifices; thus, a distortion of regular sacrificial practices introduces the re-establishment of those rituals. See R.P. Martin, 'Fire on the Mountain: $L y$ sistrata and the Lemnian Women', CA 6 (1987), 77-105; A.M. Bowie, Aristophanes: Myth, Ritual and Comedy (Cambridge 1993), 178-204.

13. N. Loraux, The Children of Athena, tr. Caroline Levine (Princeton 1993), 162.

14. H. Foley, 'The "Female Intruder" Reconsidered: Women in Aristophanes' Lysistrata and Ecclesiazusae', CP 5 (1982), 8-11; in addition to the widely accepted identification of Lysistrata with Lysimache, priestess of Athena Polias (see D.M. Lewis, 'Notes on Attic Inscriptions (II), XXIII: Who Was Lysistrata?', ABSA 1 [1955], 1-13), Foley notes that the contemporary priestess of Athena Nike was named Myrrhine while Lampito was the name of the mother of the Spartan king, and hence a priestess in public cults.

15. The Gerarai, fourteen priestesses who participated in the Anthesteria, took an oath administered by the wife of the Archon Basileus and preserved in Pseudo-Demosthenes in this form:

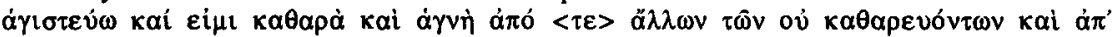

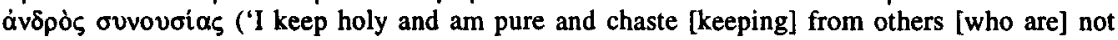
pure and from intercourse with a man', ps.-Dem. 59.73). It is significant that this oath of chastity is associated with wine sacrifices at the Anthesteria, just like the wives' oath in Lysistrata. For discussion of the sacred marriage and the role of the gerarai see N. Robertson, 'Athens' Festival of the New Wine', HSCP 95 (1993), 197-250, at 208-11; for testimonia and discussion of problems of interpretation see R. Hamilton, Choes and Anthesteria (Ann Arbor 1992), 50-58.

16. Taaffe (n.7 above), 50-52, remarks on gender identity and inversion in the Lysistrata.

17. W. Burkert, Homo Necans: An Anthropology of Ancient Greek Sacrificial Ritual and Myth, tr. Peter Bing (Berkeley 1983), 35.

18. H. von Staden, 'The Discovery of the Body: Human Dissection and its Cultural Contexts in Ancient Greece', The Yale Journal of Biology and Medicine 65 (1991), 223-41, at 230; Plescia (n.10 above, 12) discusses the connection between the sacrifice and curse: "The destruction of the victim symbolized the fate of the perjurer. The sacrifice was, in fact, a conditional curse: The oath-taker wished, in the event he did not keep the oath, to be struck like the victim which he had killed.'

19. For a brief discussion of the treatment of oaths in tragedy see J.D. Mikalson, Honor Thy Gods: Popular Religion in Greek Tragedy (Chapel Hill and London 1991), 80-87.

20. K.Sidwell, 'The Sacrifice at Aristophanes Wasps 860-890', Hermes 117 (1989), 271-77.

21. A. Brelich, 'Symbol of a Symbol', in J.M. Kitigawa and C.H. Long (eds.), Myths and Symbols: Studies in Honor of Mircea Eliade (Chicago 1969), 195-207; Burkert comments (n.17 above, 40), 'Ritual is a pattern of action redirected to serve for communication, and this means that the terms of expression are open to substitution...'

22. Obbink explores Theophrastus (as preserved in Porphyry's treatise On Abstinence), who discusses the origins of animal sacrifice as a substitution for human sacrifice. The bouphonia, for example, involves the substitution of an ox for a human victim (De. Abst. 2.29.2-4), the ploughman who slew his ox. Theophrastus posits an alimentary development in human society parallelled by changes in sacrifice. Simple vegetable products were replaced by cultivated grains, cakes, wine and honey. Due to famine humans were reduced to cannibalism and subsequently offered human sacrifice to the gods: 'Proceeding from this point they made the bodies of other animals take the place of their own in sacrifices' (De. Abst. 2.27.3). See D. Obbink, 'The Origins of Greek Sacrifice: Theophrastus on Religion and Cultural History', in R. Sharples (ed.), Theophrastean Studies: On Natural Science, Physics, Metaphysics, Ethics, Religion and Rhetoric (New Brunswick 1988), 272-95.

23. Aristophanes uses a similar device in the Acharnians, another peace play. Reckford observes: 'Things are always turning into one another, metaphorically and dramatically, in this play; it is a little like Alice. A coal scuttle may be seized and taken hostage like a baby...' Reckford's analysis of the connection between the transformations of the Acharnians is perhaps germane to the Lysistrata: 'How are all these transformations connected? Most of them seem to reflect the unnaturalness of war, its power to pervert ordinary feelings and values.' See K.J. Reckford, Aristophanes' Old-and-New Comedy (Chapel Hill 1987), i.169.

24. D. Hughes, Human Sacrifice in Ancient Greece (London 1991). Hughes concludes that there is no good evidence for the actual practice of human sacrifice in Greek cult from the 


\section{JUDITH FLETCHER}

Mycenean period onwards. Most scholars agree that myths of human sacrifice have no historical value, and as Hughes (see esp. 191) notes, its relative scarcity in epic, prevalence in Greek tragedy and increase in Hellenistic times suggest that it was a convenient narrative device rather than vestigial memory of earlier ritual.

25. Hist. An. 7.1.581a31-b2; H. King, Hippocrates' Woman: Reading the Female Body in Ancient Greece (New York 1998), 94; Burkert (n.17 above, 62) explains the 'exclusively human phenomenon of shedding blood in first intercourse' for association of sacrifice with the defloration of virgins. In an earlier work he discusses in detail the assimilation of virgin sacrifices into scapegoat mythology: W. Burkert, Structure and History in Greek Mythology and Ritual (Berkeley 1979), 72-77. Also see N. Loraux, Tragic Ways of Killing a Woman, tr. A. Forster (Cambridge MA and London 1987), 31-43, on virgin sacrifice in tragedy and the association of the sacrificial virgin and animal sacrifice.

26. Burkert (n.17 above), 58-60.

27. N. Jay, 'Sacrifice as Remedy for Having Been Born of Woman', in C.W. Atkinson, C.H. Buchanan and M.R. Miles (eds.), Immaculate and Powerful (Boston 1983), 283-309, at 283f.

28. Burkert (n.17 above), 91f.; see Obbink's discussion of the maenadic sparagmos in D. Obbink, "Dionysus Poured Out: Ancient Theories and Modern Theories of Sacrifice and Cultural Formation', in Thomas H. Carpenter and Christopher A. Faraone (eds.), Masks of Dionysus (Ithaca 1993), 65-88, at 70 ; Bowie (n. 2 above, 190) cites a rite celebrated in honour of Demeter at Hermione in which old women slaughtered four cows (Paus. 2.35.4-8). As he notes, the sacrifice deviates from normal practice: the cows run loose inside a shrine until they are killed by sickles.

29. Detienne argues that even the sacrificial slaughtering at the women's festival of the Thesmophoria would performed by the makairios: M. Detienne, 'The Violence of Wellborn Ladies: Women in the Thesmophoria', in M. Detienne and J.P. Vernant (eds.), The Cuisine of Sacrifice among the Greeks (Chicago 1989), 129-47; R. Osborne, 'Women and Sacrifice in Ancient Greece', CQ 43 (1993), 392-405, at 397.

30. King (n.25 above), 93.

31. Distribution would include selling meat from sacrificial victims at the market. See V. Rosivach, The System of Public Sacrifice in Fourth Century Athens (Atlanta 1994), at 88-89; for detailed accounts of sacrifice also see L. Ziehen, 'Opfer', in Pauly-Wissowa Realencyclopädie der klassischen Altertumswissenschaft (Stuttgart 1939), 579-627; A. Bowie, 'Greek Sacrifice: Forms and Functions', in Anton Powell (ed.), The Greek World (London and New York 1995), 463-82; Burkert (n.17 above), 1-12. Oath sacrifices featured variations of this procedure: the victim is often neither burned nor consumed.

32 They pay similar attention to the bodies of the Theban and Corinthian women. Myrrhine's comments (as she inspects the woman from Thebes) anticipate the correlation between women

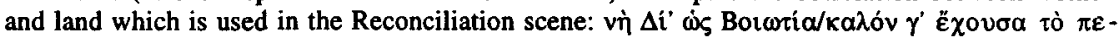
Siov ('Zeus! what a fine plot of land Boiotia has', 87f.).

33. J. Hangard, Scholia in Vespas, Pacem, Aves et Lysistratam, Fasc. iv: Scholia in Aristophanis Lysistratam (Groningen 1996), ad loc.

34. Athenaeus (7, 297d-e) discusses the sacrifice of both an eel and a tuna. According to Durand an olpe now in Berlin depicts the sacrifice of a tuna: J.L. Durand, 'Ritual as Instrumentality', in Detienne and Vernant (n.29 above), 119-28, at 127.

35. See [Xen.] Ath. Pol. 2.9 for the practice of sharing sacrificial meat among the polis; also Rosivach (n.31 above), 3-8, for further discussion.

36. C. Faraone, 'Molten Wax, Spilt Wine and Mutilated Animals: Sympathetic Magic in Near Eastern and Early Greek Oath Ceremonies', JHS 113 (1993), 60-80, at 72; Faraone cites Dictys of Crete (i 15) for the report of the bisection of a boar prior to the departure for Troy: Greek soldiers passed between the bisected halves as they swore an oath of enmity against Priam. Similar oath ceremonies involving bisected victims occur in Dictys (ii 49 and v 10). See Faraone for cross-cultural parallels in Hittite and Hebrew texts. Kirk offers evidence for the distribution of oath sacrifices: G.S.Kirk, The lliad: A Commentary Volume 1: Books 1-4 (Cambridge 1985), 304.

37. Martin (n.12 above) connects a series of allusions in Lysistrata to the Lemnian ritual of the purphoria. While it is uncertain whether the myth of the Lemnian women came before the ritual, both myth and ritual share with the Lysistrata the elements of separation of the sexes, and rule by women. At 89-92 Martin suggests that the oath sacrifice of the Lysistrata with its emphasis on the blackness of the victim and container recalls the chthonic sacrifice of the purphoria. Thus the 


\section{SACRIFICIAL BODIES IN ARISTOPHANES' LYSISTRATA}

sacrifice of the Lemnian rites is the ritual equivalent of the murder of the Lemnian husbands. Martin speculates that the murder of the husbands in the Lemnian myth is analogous to the 'killing' of men by the sex strike in the Lysistrata ; however for my purposes it is sufficient to note that the Lemnian allusions help to emphasise the transgressive nature of the women's sacrifices.

38. Detienne (n.29 above), 131.

39. Bowie (n.12 above, 182) notes that the women's actions 'are both a declaration of war and an attempt to make peace'.

40. Burkert (n.17 above), 164.

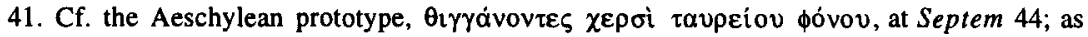
Faraone suggests (n.36 above), the elliptical wording suggests a self-imprecation linking the fate of the sacrificed bull with that of the heroes should they fail. See also Plescia (n.10 above), 12. Kirk (n.36 above, 304) comments on the practice of distributing the hairs of the victim before an oath sacrifice as a variation of this practice.

42. Just before they took their oath Lysistrata had suggested that they swear 'not to pour water in the cup' (197). Sommerstein takes this to be a metaphor: the cup is the vagina, the water 'its lubricating secretion' (A.H. Sommerstein [ed. and comm.], Lysistrata [Warminster 1990], ad loc). But if we accept this correspondence, then the women's curse is rather circular: that they will have sexual intercourse...if they have sexual intercourse.

43. Eustathius is commenting on the famous oath which the Trojans and Greeks take to mark their peace treaty (Iliad 3.292-301): three victims slaughtered and wine poured on the ground. The wine is not consumed because it symbolises the fate of any would-be perjurers. Burkert cites a Molossian oath ceremony for a similar practice: W. Burkert, Greek Religion, tr. John Raffan (Cambridge MA 1985), at 251; but see Kirk (n.36 above), 304.

44. Martin (n.12 above); Bowie (n.12 above); C. Faraone, 'Salvation and Female Heroics in the Parodos of Aristophanes' Lysistrata', JHS 117 (1997), 38-59.

45. Henderson (n. 8 above), 95.

46. The oracle functions as a speech act in this play regardless of the fact that it is a written text, because it is read aloud by Lysistrata. The effect of the oracle is in fact performative, as I argue. See Petrey's discussion (n.6 above, 42-56) on the performative capacity of written texts.

47. See Henderson for erotic connotations of sacrificial terminology: J.Henderson, The Maculate Muse: Obscene Language in Attic Comedy (Oxford 1975), 177.

48. D. Konstan, 'Aristophanes' Lysistrata: Women and the Body Politic', in A. Sommerstein, S. Halliwell, J. Henderson and B. Zimmermann (eds.), Papers from the Greek Drama Conference (Nottingham 1993), 431-44.

49. Other examples of such objectifications in Aristophanes: the Peace Treaties in Knights 1389-95; Vintage and Festival in Peace 523-26, 706-14, 871-76, 1329-57. Stafford investigates the use of feminine forms in personified abstractions in Greek art and literature and concludes that while the convention may have its origins in the grammatical gender, the use of the female body expresses the desirability of the values represented: E.J. Stafford, 'Masculine Values, Feminine Forms: On the Gender of Personified Abstractions', in L. Foxhall and J. Salmon (eds.), Thinking Men: Masculinity and its Self-Representation in the Classical Tradition (New York 1998), 43-56. Also see B. Zweig 'The Mute Nude Female Characters in Aristophanes' Plays', in A. Richlin (ed.), Pornography and Representation in Greece and Rome (Oxford 1992), 73-89, who argues that while male characters might be insulted and abused in Old Comedy, they are not deprived of speech as female characters are. Lysistrata's treatment of Diallage aligns her with comic male characters who handle naked flute girls and the like. It is of course impossible to determine whether mute nude female characters such as Diallage were represented by costumed male actors or by real women (hetairai), yet as Zweig observes the ideological implications of scenes involving naked, silent women would be identical whether or not the roles were played by real women.

50. Taaffe (n.7 above), 71 remarks: ' ...woman has been put back in one of her rightful places, as a silent token of exchange between men.'

51. I am grateful to Richard Hamilton and Ian Hember for commenting on earlier drafts of this article. Different versions were presented at the following conferences and meetings: The Classical Association of Canada, Ottawa, June 1998; The American Philological Association, Washington, D.C., December 1998; Personification in Ancient Art and Literature, London, England, September 2000 (made possible by Wilfrid Laurier University's international conference grant). 